\title{
Can corporate taxation be explained by limited liability?*
}

\author{
Anton Miglo ${ }^{\dagger}$
}

December 2008

\begin{abstract}
We consider a model where wealth-constrained entrepreneurs have private information about the qualities of available investment projects. We show that some "high risk-high return" projects will receive external financing even if they are not socially profitable. Some "low risk-low return" projects will not be funded even if they are socially profitable. Government interventions can improve equilibrium. Optimal government policy may include corporate taxation, subsidies or other instruments. A universal tax on all entrepreneurs with limited liability is not optimal.
\end{abstract}

*I thank James Amegashie, Henry Thille, and the seminar participants at the University of Guelph for useful suggestions and comments.

†University of Guelph, Department of Economics, Guelph, Ontario, Canada, N1G 2W1, tel. (519) 824-4120, ext. 53054, email: amiglo@uoguelph.ca 


\section{Introduction.}

Traditional "folk" opinion is that corporate tax is the price corporations pay for the right of limited liability. However, there is no formal proof of this argument. Musgrave and Musgrave (1980) and Rosen (2004) noticed that it is hard to believe in the link between the real amount of benefits corporations receive from limited liability and the magnitude of corporate taxation.

We turn to asymmetric information to address the issue. We consider an environment where entrepreneurs choose between risky projects, with high potential profitability, and safe projects, with minimal profitability. An entrepreneur's incentive depends on the financing contracts. There are two contracts available: one with limited liability and one with unlimited liability. The entrepreneurs choose contracts based on a trade-off between interest rates (unlimited liability contracts have a lower interest rate) and a loss in the bad state (limited liability contracts do not imply a loss for the entrepreneur in the bad state). If the project fails and an entrepreneur faces unlimited limited liability, then in addition to be forced to cover a firm's loss the entrepreneur sustains additional costs such as, for example, relocation costs (in case he has to sell his house) and reputation costs. ${ }^{1}$ We argue that the equilibrium is inefficient: some entrepreneurs use limited liability contracts and invest inefficiently (overinvestment problem) and some of them do not undertake socially efficient projects (underinvestment). Although corporate taxation reduces the incentive to overinvest it does not mitigate the underinvestment problem. Optimal government policy includes a combination of corporate taxation, subsidies and other instruments.

\section{The model.}

Consider a set of entrepreneurs, indexed by $j$, with investment projects available. Projects require the same amount of external financing equal to 1 . In the case of success a project generates a cash flow $F_{j}$ and a cash flow of zero otherwise. $^{2}$ The probability of success is $p_{j}$. There is also a risk-free invest-

\footnotetext{
${ }^{1}$ Becker and Fuest (2007) explore a different approach based on entrepreneur's opportunities to off-set losses and come to a different conclusion regarding optimal government policy. See comment in footnote 2 regarding the model in their paper.

${ }^{2}$ The present model is more general than one in Becker and Fuest (2007) where the cash flows are the same across the projects in the case of project's success.
} 
ment project with cash flow $I<F_{j}-1$. There are two types of financing available for the risky project. One is a limited liability contract (LLC). Here, an entrepreneur borrows an amount 1 from a bank. In the case of success, the entrepreneur pays $D$ to the bank. If the project fails the parties have no returns. Alternatively, the entrepreneur can use an unlimited liability contract (ULC). It is assumed that each entrepreneur has sufficient collateral, equal to 1 . Hence, ULC represents a risk-free debt for the bank and thus has a face value of 1 . If an entrepreneur has ULC and the project fails then in addition to losing collateral there is cost $r$ for entrepreneur, $r>0$. For instance, if the entrepreneur has to sell his house there is cost of new house search and moving cost. There might also be additional costs for family members due to moving to a new location. $F_{j}$ and $p_{j}$ are the private information of each entrepreneur. Banks do not have this information. Entrepreneurs and banks are risk-neutral.

\section{Underinvestment and overinvestment.}

The following equation separates socially efficient risky projects from socially inefficient projects:

$$
p_{j} F_{j}-1=I
$$

If the left side is greater, the project is socially efficient and vice versa. For marginal entrepreneurs (marginal entrepreneurs' projects satisfy (1)) $\partial p_{j} / \partial F_{j}=-(1+I) / F_{j}^{2}<0$ and $\partial^{2} p_{j} / \partial F_{j}^{2}=2(1+I) / F_{j}^{3}>0$.

We have the following set of equations which determine an equilibrium. The choice between the LLC and the risk-free project is given by:

$$
p_{j}\left(F_{j}-D\right)=I
$$

where $D=1 / p^{*}$ and $p^{*}$ is the average probability of success among the entrepreneurs with a LLC. For this equation we also have $\partial p_{j} / \partial F_{j}<0$ and $\partial^{2} p_{j} / \partial F_{j}^{2}>0$. If an entrepreneur's project satisfies (2) he is indifferent between the LLC and the risk-free project. If the left side is greater, the entrepreneur chooses the LLC and vice versa.

The choice between the LLC and the ULC is given by:

$$
p_{j}\left(F_{j}-1 / p^{*}\right)=p_{j}\left(F_{j}-1\right)-\left(1-p_{j}\right)(1+r)
$$


This equation can be rewritten as:

$$
p_{j}=\frac{1+r}{r+1 / p^{*}}
$$

and the choice between the ULC and the risk-free project is given by:

$$
p_{j}\left(F_{j}-1\right)-\left(1-p_{j}\right)(1+r)=I
$$

The analysis of equations (1)-(4) reveals the following. (a) From (1) and (2) the marginal entrepreneur with $p_{j}=p^{*}$ is indifferent between the LLC and the risk-free project. (b) From (1) and (3) marginal entrepreneurs with $p_{j}=p^{*}$ prefer the LLC to the ULC. This is because the right side of (3) is greater than $p^{*}$ since $r>0$. (c) Marginal entrepreneurs prefer the risk-free project to the ULC. To see this let us rewrite (1) and (4) as follows:

$$
\begin{gathered}
p_{j}=(1+I) / F_{j} \\
p_{j}=(I+1+r) /\left(F_{j}+r\right)
\end{gathered}
$$

The right side of (6) is greater than that of (5) because $F_{j}>1+I$.

Figure 1 illustrates the equilibrium decision-making for the entrepreneurs. The thick lines represent equations (1)-(4). Letters $f, l$ and $u$ denote the areas where the entrepreneurs choose the risk-free contract, the limited liability contract, or the unlimited liability contract respectively.

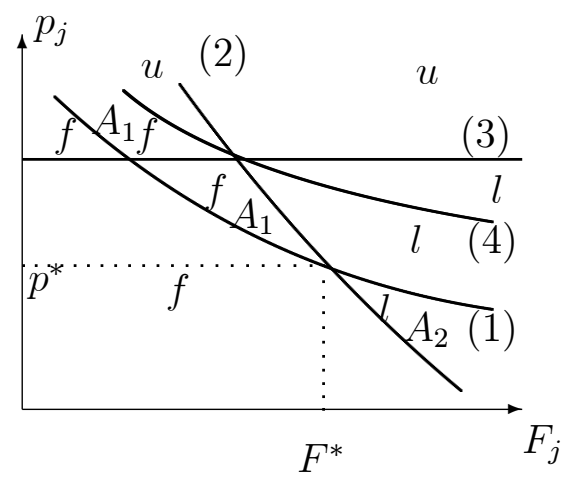

Figure 1. Overinvestment and underinvestment. 
From the remark (a) above the point of intersection of (1) and (2) has the probability of success $p_{j}=p^{*}$. The intersection is unique since the slope of (1) is greater than that of (2): $-\frac{1+I}{F_{j}^{2}}=-\frac{p^{2}}{1+I}>-\frac{I}{\left(F_{j}-D\right)^{2}}=-\frac{p^{2}}{I}$. From (b) the line corresponding to (3) lies above the line $p_{j}=p^{*}$. From (c) the line corresponding to (4) lies above the line corresponding to (1).

As follows from Figure 1, there are two areas of inefficiency. Firms in area $A_{1}$ underinvest and firms in area $A_{2}$ overinvest (and use the LLC). What explains these results?

First, consider entrepreneurs with unlimited liability. Suppose $C=0$. The unlimited liability contract is a risk-free debt for the bank. Thus, the entrepreneur's expected earnings equal the project's expected earnings $\left(p_{j} F_{j}\right)$ reduced by the payment to the bank (which equals the investment cost 1 ). This means that under unlimited liability, entrepreneurs will not invest in socially inefficient projects because they are always better-off with the riskfree investment (eq. (1)). The same holds if $C>0$ because in this case entrepreneurs earn even less than when $C=0$ (line (4) lies above the line (1)).

Secondly, consider entrepreneurs with limited liability. From (1) marginal entrepreneurs have projects with equal expected values. In area $A_{2}$ marginal entrepreneurs have lower probabilities of success than $p^{*}$ (the average probability of success among entrepreneurs with limited liability contracts). A higher probability of default is detrimental for creditors. Thus, marginal entrepreneurs in area $A_{2}$ make a positive surplus compared to the symmetric information case. This implies that there are some entrepreneurs with a lower probability of success than marginal entrepreneurs which will choose limited liability investment in risky projects (similar to the asset substitution effect). ${ }^{3}$ On the other hand, marginal entrepreneurs in area $A_{1}$ have a higher probability of success which is beneficial for creditors and harmful for shareholders because they receive a lower return in the good state. Thus, some entrepreneurs with a high probability of success will not invest in socially efficient risky projects. Optimal government policy will include a tax on entrepreneurs with limited liability contracts and high earnings (high $F_{j}$ ) and subsidies for entrepreneurs with limited or unlimited liability contracts and low earnings (low $F_{j}$ ). ${ }^{4}$ This will move line $(2)$ toward line (1) reducing

\footnotetext{
${ }^{3}$ DeMeza and Webb (1987).

${ }^{4}$ Mathematical calculations of the optimal tax rate and the amount of subsidies are omitted for brevity. Note that they depend on whether the government is able to observe
} 
areas $A_{1}$ and $A_{2} \cdot{ }^{5}$ A universal tax on all entrepreneurs with limited liability is never optimal because it will move line (2) up and to the right, increasing area $A_{1}$.

\section{References}

Becker, J., and C. Fuest, 2007, Why is there corporate taxation? The role of limited liability revisited, Journal of Economics 92(1), 1-10.

DeMeza, D., and D. Webb, 1987, Two much investment: a problem of asymmetric information, Quarterly Journal of Economics 102, 281-92.

Musgrave, R., and P. Musgrave, 1980, Public finance in theory and practice, McGraw-Tokyo.

Rosen, H. Public Finance. McGraw-Hill/Irwin; 7 edition, 2004.

(ex-post) the type of entrepreneur or only the amount of earnings.

${ }^{5}$ It is assumed that all entrepreneurs have sufficient collateral (that makes debt risk-free for banks). It can be shown that if this assumption is relaxed one can have an equilibrium where some entrepreneurs with unlimited liability overinvest. Thus, optimal policy may include taxes on some entrepreneurs with unlimited liability. 